\title{
Kırgızistan’ın Bürokratik Kurumlarında Siyasetin Etkisi: İşe Alma ve Tasfiye Uygulamaları
}

The Effect of Politics on the Bureaucratic Institutions of Kyrgyzstan: Recruitment and Dismissal Practices

$$
\text { Ömer Faruk Karaman }{ }^{*} \text { (D) Haluk Alkan² }
$$

${ }^{1}$ Department of International Relations, Kyrgyz-Turkish Manas University, Bishkek, Kyrgyzstan

${ }^{2}$ Department of Political Science and International Relations, Istanbul University, Istanbul, Turkey

\begin{abstract}
Received: 00.00.2021
Accepted: 00.00.2021

This article was checked by intihal.net

\section{Özet}

Siyaset ile bürokrasi arasındaki ilişkilerin yasal kurum ve kurallar etrafında şekillenmesi ideal tip bürokrasilerin özelliklerindendir. Buna karşın siyasetin bürokrasi üzerindeki yoğun etkisi ve gayri şahsi ilişkiler, patrimonyal bürokrasileri ortaya çıkarır. Günümüzde bu tarz ilişkilerin söz konusu olduğu ülkelerde yasal-rasyonel kurumların bulunmasının yanı sıra kişisel ilişki ağlarının bürokrasiyi şekillendirmesi neopatrimonyal bir yönetim tarzının benimsendiğini ortaya koyar. Sovyetler Birliği'nin dağılmasından sonra ortaya çıkan bağımsız Orta Asya ülkelerinin yönetim tarzında bazı benzerlikler ve farklılıklar vardır. Kırgızistan'ın bağımsızlığını kazanmasından sonra ortaya çıkan siyaset-bürokrasi ilişkisini temellendiren unsurların başında klan siyaseti, bölgesel ve yerel liderlik yapıları, hemşericilik ve akrabalık ilişkileri gelmektedir. Bu çıkar gruplarının cumhurbaşkanı etrafında kümeleşmesiyle ortaya çıkan bu ilişkiler, kamu kurumlarındaki insan kaynakları politikalarını doğrudan etkilemektedir. Bu durum kurumlardaki yolsuzlukların önünü açan en önemli etkenlerden kabul edilmektedir. Neopatrimonyalizm teorisi temeline oturtulan bu çalışmada Kırgızistan'daki bürokratik kurumların siyasi aktörlerin güdümüne girerek asli vazifesi olan kamu hizmetlerinin aksatılmasına neden olduğu yapılan literatür taraması ve mülakatlar neticesinde ortaya koyulmuştur.
\end{abstract}

Anahtar Kelimeler: Kırgızistan, neopatrimonyalizm, siyaset, bürokrasi, işe alma, tasfiye

\section{Abstract}

One of the characteristics of ideal type bureaucracies is that the relations between politics and bureaucracy are shaped on the basis of legal institutions and rules. On the contrary, the intense influence of politics on bureaucracy and impersonal relations reveal patrimonial bureaucracies. Today, the existence of legal-rational institutions in countries where such relationships take place, as well as the formation of bureaucracy by personal relations networks reveal that a neopatrimonial management style has been adopted. There are some similarities and differences in the management style of the Central Asian countries that emerged after the collapse of the Soviet Union. Clan politics, regional and local leadership structures, fellowship and kinship relations are the main factors that base the politics-bureaucracy relationship that emerged after Kyrgyzstan's independence. These relations, which emerge as these interest groups cluster around the president, directly affect the human resources policies in public institutions. This situation is regarded as one of the most important factors that paves the way for corruption in institutions. This study is based on the theory of neopatrimonialism. It has been determined that bureaucratic institutions in Kyrgyzstan are under the control of political actors, and public services, which is the main duty of the bureaucracy, cause disruptions.

Keywords: Kyrgyzstan, neopatrimonialism, politics, bureaucracy, recruitment, dismissal

Karaman, Ö.F., \& Alkan, H. (2021). Kırgızistan'ın Bürokratik Kurumlarında Siyasetin Etkisi: İşe Alma ve Tasfiye Uygulamaları. Journal of Academic Value Studies, 7(4), 492-502. http://dx.doi.org/10.29228/javs.52851

\footnotetext{
*E-mail address: omer.karaman@manas.edu.kg (Corresponding Author)
} 


\section{Giriş}

Bürokrasi kavramının halk dilinde genel olarak olumsuz anlamları bulunmaktadır. Bu olumsuz algı, bilimsel çerçevede "bürokratizm" veya "büropatoloji" olarak ele alınmaktadır. Bununla birlikte bürokrasi kapsamı yalnızca devlet yönetimindeki işler ve onları icra edenler olarak tanımlanmamakta, aynı zamanda büyük ölçekli oluşumlardaki örgütlenme şeklini de ifade etmektedir. Bu konuda ilk araştırmaları gerçekleştiren Alman sosyolog Max Weber, bürokrasiyi rasyonel bir örgütlenme ve yönetme şekli olarak ele almış ve özelliklerini belirtmiştir. Bu kapsamda 'ideal tip' olarak adlandırdığı rasyonel bürokrasi ve geleneksel otoritelerde yaygın olarak uygulanan patrimonyal bürokrasileri incelemiştir (Dursun, 1992, s. 134).

Weber, geleneksel otoritelerin hakim olduğu ülkelerde, yöneticinin (efendinin) devletin tüm imkanlarını kendi kişisel araçları gibi kullanmasına dayanan yönetim anlayışını patrimonyalizm, bu sistemin daha ilerisini de sultanizm olarak tanımlamıştır. Yöneticinin bu aşamada yönetim ekibiyle olan karşııklı fayda ilişkileri de oldukça yaygındır. Dolayısıyla yöneticinin bu şekilde devlet yönetimi ve bürokrasideki hakimiyetini devam ettirebilmesi için çevresindeki gruplara lütuflarda bulunması söz konusu olmaktadır. Doğal olarak bu sistemin temelinde liyakat yerine sadakat bulunmaktadır (Weber, 2012, s. 351). Bu kavramı modern dünya devletlerine uygulayanlar ise Guenther Roth ve Shmuel Eisenstadt olmuştur. Onlar, patrimonyal bir yapıya sahip olan Afrika ve Latin Amerika ülkelerini tanımlarken neopatrimonyalizm kavramını kullanmışlardır. Geleneksel topluluklardaki patrimonyalizm türünü ifade eden bu kavram, patrimonyal uygulamalar ile birlikte yasal-ussal kurumların ve normların bir arada varlığını sürdürdüğünü açıklar. Dolayısıyla bu kavram, devletin hem bürokratikleşmesini hem de patrimonyallaşmasını ifade eder (Bach, 2011, s. 275277). Bu tarz devlet yönetiminde kurumlardan ziyade şahıslara önem atfedilir. Resmî kurumlarda kişisel ilişkiler yaygın olmakla beraber, yöneticiler kişisel servet ve pozisyon elde etmek için çaba gösterirler. Dolayısıyla bürokratik kurumlarda kamu hizmeti temel amaç olmaktan çıkarak şahsi çıkarların gölgesinde kalır (Bratton, 1994, s. 458).

Bürokrasinin Sovyetler Birliği döneminde organik bir yere sahip olduğu bilinmektedir. Öyle ki, devlet/siyasetbürokrasi bütünleşmesinden söz edilebilmektedir. Üretim araçlarının devletleştirilmesinden dolayı bireylerin sömürülmesi, bireysel değil kolektif anlamda gerçekleşmekteydi. Bu sistemi ve üretim araçlarını elinde bulunduran bürokratik yapı, toplumun tamamına hükmedebilmekteydi (Çevikbaş, 2014, s. 92). Sovyetler Birliği'nin bürokratik yapısını elinde tutan yönetici sınıfı ise nomenklatura olarak adlandırımaktaydı. Komünist Parti seçkinlerinden meydana gelen bu yapı özellikle Stalin döneminde güç kazanmıştı. Partinin karar verici mekanizmaları tarafından onaylanan ve bu guruba dahil edilen kişiler bürokrasideki tüm işleyişi belli bir ideolojik çerçevede kontrol etmekteydi (Voslenskiy, 1990, s. 15). Fakat bu yapı özellikle Glasnost ve Perestroyka olarak adlandırılan yumuşama döneminde, sahip oldukları ideoloji dışında kendi menfaatleri doğrultusunda kararlar alarak kurumları işletmeye başlamışlardır. Bu durum da Sovyetler Birliği'ni dağılma aşamasına getiren etkenlerden biri olmuştur (Livşin, 2018, s. 32).

Sovyetler Birliği'nin dağılmasından sonra ortaya çıkan devletlerin bazılarında bürokratik anlamda neopatrimonyal uygulamalar görülmeye başlanmıştır. Kırgızistan da bu ülkelerden biri olarak sayılabilmektedir. Weingrod'a göre neopatrimonyal sistemlerin özelliklerine bakıldığında patronaj ağları bağlamında patron-müşteri (client) ilişkilerinin yaygın olduğu, bu çerçevede liderin ve onun etrafında kümeleşen grupların karşııklı çıkar esasına dayalı olarak başka şahıs veya gruplara devlet kurumları üzerinden çeşitli imkanları sağlanması söz konusudur. Bu ilişki ağına dahil olanlar ise hiyerarşik bir yapı içerisinde bulunur ve bu yapının tepesinde devlet başkanı yer alır (Weingrod, 1968, s. 377). Bununla birlikte karşılıklı ilişkiler ağında sadakatin dışına çıkıldığında şantaj ilişkileri ortaya çıkabilmektedir. Karşılıklı şekilde elde bulundurulan suç delilleri, sadakatin sabit tutulmasını sağlamaktadır (Melnikov, 2017, s. 73). Bu tür ilişkiler Sovyetler Birliği'nin dağılmasından sonra oluşan devletlerde yasal-rasyonel kurum ve kuralların varlığına rağmen ortaya çıkmış ve devlet başkanının merkezinde patron-müşteri ilişki ağının yerleşmesi söz konusu olmuştur (Fisun, 2012, s. 90).

Orta Asya'da bağımsızlıklarını kazanan devletlerde Sovyetler Birliği dönemindeki yönetici kadroların yönetim süreçleri devam etmiş, hatta lideri merkeze alan anayasaların oluşturulması söz konusu olmuştu. Bundan dolayı bu ülkelerde devlet başkanına bağımlı bir siyaset ve yönetim tarzı geliştirilmişti. Fakat bu ülkeler arasında Kırgızistan'da bu süreç daha farklı ilerlemiştir. Çok partili ve muhalefetin mevcut olduğu bir siyasal sistemin içinde, bölgecilik ve klan siyaseti etrafındaki ittifaklarla temellenen bir yapıdan söz edilebilmektedir (Alkan, 2012, s. 24). Kırgızistan'daki 
neopatrimonyal uygulamaların temelinde kuzey-güney eksenli kutuplaşma yer almıştır. Ülkedeki bu ayrışma iki farklı bölgede yaşayan Kırgız toplumlarının sahip olduğu sosyo-kültürel çeşitlilikten kaynaklanmaktadır. Hem Sovyet hem de Post-Sovyet dönemde ortaya çıkan bölgecilik, kabilecilik, hemşericilik gibi unsurların temelinde yine bu neden bulunmaktadır. Fakat günümüzde Kırgızistan'da gözlemlenen patron-müşteri ilişkilerinin yalnızca bu nedene dayandırılması doğru olmayabilir. Bazı durumlarda Kırgızistan'da bölgesel (kuzey-güney) liderlik yapılarının siyasal seçkinlerle ittifak kurmaları ve bu doğrultuda patronaj ilişkilerinin geliştirilmesi söz konusudur. Bu şekilde gelişen neopatrimonyal uygulamalar çerçevesinde ülkedeki bürokratik kurumlarda çalıştırılmak üzere işe alınanlarda liyakat yerine sadakatin arandığı durumu vardır. Genellikle karşılıklı menfaat ilişkileri çerçevesinde işe alma süreci gerçekleşmektedir (Sultanbekov, 2016, s. 109-110).

Bu çalışmada, neopatrimonyalizm çerçevesinde ele alınmak suretiyle Kırgızistan’ın bağımsızlığından sonra bürokratik kurumlarında ortaya çıkan ilişkiler bağlamında, işe alma ve işten çıkarma prosedürü incelenmiş, resmi ve gayri resmi uygulamalar saptanmaya çalışılmıştır. Çalışma hazırlanırken Kırgızistan'daki bürokratik kurumlar ve yapıları incelenmiş ve bu kurumları etkileyen dinamikler irdelenmiştir. Nitel ve betimleyici bir araştırmayı teşkil eden bu çalışmada Türkçe, Kırgızca, İngilizce ve Rusça birincil ve ikincil kaynaklar taranmıştır. Bununla birlikte Kırgız bürokrasisinde çalışmış veya çalışmakta olan bürokratlarla, akademisyenlerle ve siyasilerle gerçekleştirilen mülakatlar yine birincil kaynaklara dahil edilmiştir. Aynı zamanda yazarın sahada geçirmiş olduğu on dört yıllık sürenin ışı̆̆ında gözlem metodu da uygulanmıştır.

\section{Bürokrasi ve Özellikleri}

Devlet işlerinin icra edildiği ofisler anlamını taşıyan "bureau" ile hakimiyet anlamını taşıyan "cratie" sözcüklerinin birleşmesinden oluşan "bürokrasi" kavramı doğal olarak devlet dairelerinin iktidarını ifade etmektedir. Günümüzde ise bu kavram devlet dairelerinin işleyişi ve bunu işleten personeli açıklamaktadır (Dursun, 1992, s. 133). Halk arasında farklı şekillerde algılanan bu ifade aynı zamanda yapısal ve davranışsal özellikleri açısından da ele alınmaktadır. Zira bürokrasinin yapısal özellikleri, aynı zamanda işleyişi hakkında bilgiler sunabilmektedir. Bu özellikler genel olarak "kırtasiyecilik ve verimsizlik", "rasyonel örgüt biçimi", "kamu yönetimi" ve "büyük ölçekli örgütler" olmak üzere tanımlanabilmektedir (Eryılmaz, 2012, s. 262-263).

Bürokrasinin olumsuz anlamlarını taşıyan kırtasiyecilik ve verimsizlik, kamu kurumlarındaki gereksiz iş yükünü, işlerin ağır ilerleyişini, kurumsal hantalığını, departmanlar arasındaki imza dolaşımını ifade etmektedir (Çevikbaş, 2014, s. 79). Weberi'in bürokrasinin tanımında kullandığı rasyonel örgüt biçimi ise bürokrasinin rasyonel bir şekilde teşkilatlanmasını, belirlenmiş bir iş bölümünün olmasını, dosyalama ve kayıt işlemlerinin gerçekleşmesini, üst kademenin ast kademeyi denetleyebildiği hiyerarşik bir yapının varlığını, şahsi ilişkilerden arınmış ve resmi kuralların belirlediği yetkiler dahilinde icra işlemlerinin yapıldığı bir yapıyı ifade etmektedir. Diğer yandan devlet yönetiminde idari işleri gerçekleştirme anlamı taşıyan kamu yönetimi, bürokrasi ile aynı anlamlara gelmektedir (Eryılmaz, 2012, s. 263-264).

Weber, bürokrasiyi iki farklı grupta ele almıştır. İlk olarak patrimonyal bürokrasilerde otoriteye bağımlı olan bir memur kitlesinden bahsetmiştir. Bu tarz bürokrasilerde kurum ve kurallardan ziyade kişiler ve manevi değerler önemlidir. Geleneksel otorite türüne dayanan bu toplumlarda, devlet yöneticisi halkın babası olarak addedilir ve devletin araçları da onun kişisel mülkü olarak görülür. Bu nedenle kamu hizmetleri işleri de devlet yöneticisinin şahsi işleri olarak algılanır (Eryılmaz, 2012, s. 271). Böylece, kişisel sadakatin hakim olduğu ve ataerkil bir yönetim tarzının benimsendiği geleneksel otoriteler, patrimonyal bürokrasilerin ortaya çıkmasında etkili olan en önemli faktörlerdendir. Bu sistemlerin diğer bir özelliği de keyfi uygulamaların yaygın olmasıdır (Lai, 2014, s. 43). Weber bu tarz yönetim anlayışının eski Mısır, Roma ve Bizans imparatorluklarında, Ortaçağ Katolik Kilisesi'nde ve Çin'de yaygın olarak görüldüğünü aktarmıştır (Weber, 2004, s. 301).

Weber, patrimonyal bürokrasi dışında yasal-rasyonel otoritelerin hüküm sürdüğü ülkelerdeki bürokrasilerden bahsetmiştir. Weberyan bürokrasi olarak da adlandırılabilen bu tip bürokrasilerde, yasal çerçevede belirlenmiş görev tanımları, sınırları belirlenmiş yetkililer, gayri şahsi ilişkilerden arındırımış profesyonel bir uzmanlık ağı, üstünün astını kontrol edebildiği hiyerarşik yapı ve dosyalama/kayıt altına alma işlemleri söz konusudur (Aydın, 2017, s. 1000). Weber, profesyonellikten uzak olan patrimonyal sistemlerin aksine bürokrasiyi ideal olarak tanımlamıştır. İdeal tip bir bürokrasi oluşumunu da piyasa sermayesine bağıı bir sisteme dayandırmıştır. Bunun için doğal olarak da demokratik bir ortama 
da ihtiyaç duyulduğunu aktarmıştır (Peachey, 1006, s. 26). Ona göre devlet memurlarının icra ettikleri hizmet karşısında ücret almaları, bürokratikleşmenin en önemli unsurlarındandır. Para ekonomisinin ve sabit gelirin olmadığı yapılar zamanla farklı oluşumlara dönüşebilecektir (Weber, 2017, s. 229). Bu sistemde şahsiliğe, keyfiliğe ve duygusallğa yer verilmez. Zira bu sistem meşruluğunu yasalardan ve rasyonellikten alır. Ayrıca bu sistemler yalnızca devlet kurumlarına özgü değil, herhangi bir örgütlenmenin yönetim biçimi olabileceğini vurgulamıştır (Dursun, 1992, s. 141).

Bürokrasi kuramı incelenirken Hegel ve Marx'ın düşünceleri de ele alınmaktadır. Devleti bir organizmaya benzeten Hegel'in bürokrasi kuramında kamu hizmetlerinde yürütme işleri nesnelliğe dayanmalıdır. Uzman kişiler çerçevesinde hiyerarşik olarak yapılanmış olan bürokrasi toplumun çıkarlarını devlet çıkarına dönüştürür. Hiyerarşik yapı, iktidar tarafından bürokratik kurumların kötüye kullanımını da en aza indirgeyebilecektir. Bu açıdan Wilson ve Weber'in bürokrasi kuramlarına da benzerlik gösterir. Ona göre bürokrasi, toplum ve devlet arasında bir köprü vazifesini üstlenmelidir (Sager ve Rosser, 2009, s. 1142). Ayrıca Hegel'in kuramına göre ekonomik toplum ile anayasal devlet arasındaki ayrım, bürokrasinin mantığını teşkil etmektedir (Shaw, 1992, s. 387). Devlet memurlarını, evrensel çıkarlara hizmet ettiğinden dolayı evrensel bir sınıf olarak tanımlayan Hegel, kamu hizmetinde görev alma kriterinin doğum ya da statü değil, bilgi, tecrübe ve yarışma çerçevesinde olması gerektiğini belirtmiştir. Bu şekilde de sosyal tabakalaşmanın önüne geçilerek eşitlikçi bir toplum yapısı ortaya çıkacaktır (Hegel, 2001, s. 235-239). Marx ise Weber'e karşı olarak sınıf mücadelesinin son bulmasıyla bürokrasinin de ortadan kalkacağı inancını taşır. Zira o, bürokrasiyi kapitalist düzene hizmet eden bir araç olarak tanımlamıştır (Akçakaya, 2016, s. 679).

Weber, devlet kurumlarında şahsi ilişkilerin ön plana çıkması ve bu kurumların devlet yöneticisinin kişisel aracı gibi kullanmasını patrimonyalizm olarak adlandırmıştı. Günümüz dünyasında Afrika ve Latin Amerika'daki ülkelerde gözlemlenen bu durumu açıklamak için neopatrimonyalizm kavramı kullanılmış olsa da artık bu ifade evrensel bir anlam kazanmış durumdadır. Bu tarz yönetimlerin en belirgin özellikleri patrimonyal uygulamaların yanında yasal-rasyonel kurumların da bulunmasıdır. Bu sistemlerde devlet politikaları belli kişilerin çıkarlarını maksimize etmek amacıyla belirlenir ve devlet kurumları asli görevleri olan kamu hizmetini yerine getiremezler (Erdman ve Engel, 2007, s. 105). Kişisel bağlantıların önem arz ettiği neopatrimonyal devletlerde siyasi kararlar şahsi çıkarlarla örtüşür. Adam kayırmacılık, yolsuzluk, rüşvet gibi olgular da bu sistemlerde doğal bir sonuç olarak ortaya çıkar. Merkezi otorite ise patronaj ağları sayesinde iktidarlarının istikrarını sağlamaya çalışılar (Kunysz, 2012, s. 2-3). Resmi ve gayri resmi oluşumların bir arada bulunduğu bu sistemde lidere olan sadakat karşısında müşteri (client) konumundakiler maddi çıkar elde ederler. Bu sistemin Orta Asya'daki şekillenmesi devlet başkanı ve yerel güç grupları arasındaki patronaj ilişkilere dayanır. Bu iki gücün arasındaki ilişkinin temelini ise siyasi ve ekonomik güç elde etme oluşturur (Ilkhamov, 2007, s. 66-74).

\section{Kırgız Bürokrasisinde Resmi Kadrolaşma Prosedürü}

Kırgızistan'daki resmi kadrolaşma süreci Devlet Personel Servisi (DPS) tarafından işletilir. DPS'nin tüzüğünde ülkedeki kamu hizmeti ve yerel yönetimlerdeki personel politikalarını belirleyen ve seçme işlemlerini gerçekleştiren yetkili kurum olduğu ifade edilmektedir. Bununla birlikte devlet memurlarının yerleştirilmesi, meslek içi eğitimi, staj programları gibi uygulamadan sorumlu kurum olduğu belirtilmektedir. DPS'nin bağlı ve sorumlu olduğu kurum ise cumhurbaşkanlığı makamıdır. Tüzükte yer alan maddelere göre DPS memurların meşru haklarını gözetlemek ve korumakla yükümlüdür. Devlet kurumlarındaki boş pozisyonlar için rekabetçi seçim sürecini başlatmak, aday seçimi yapmak, terfi işlemlerini gerçekleştirmek, performans değerlendirmek gibi konularda da DPS yetkili organdır (mkk.gov.kg).

Kırgızistan'ın bürokratik kurumlarındaki insan kaynakları yönetiminin yasal dayanağı ülkenin bağımsızlığından itibaren başlayan bir dizi reformlar yoluyla hazırlanmaya çalışılmıştır. Bu bağlamda 2004'te 'Kamu Hizmetleri Yasası' kabul edilmiş, 2006, 2007, 2008, 2009 ve 2010 yıllarında değişikliklere uğramıştır. Ayrıca 2001'de 'Kamu Görevlileri Etiği Yönetmeliği', 2009'da 'Yolsuzlukla Mücadele Ulusal Stratejisi', 'Kırgız Cumhuriyeti İ̧̧ Kanunu' da cumhurbaşkanları tarafından onaylanan kamu personeline yönelik yasal mevzuatı teşkil etmektedir (Liebert, 2014, s. 405-406).

DPS'nin 2019 verilerine bakıldığında Kırgızistan'da yerel yönetimlerin de dahil olduğu kamu sektöründe çalışanların sayısının 26.646 olduğu görülmektedir. Bu sayının \%2,5'lik kısmı en üst kademedeki yöneticilerden oluşmakta. Kamu hizmetinde görev yapanların çalıştığı sürelere bakıldığında 6-10 yıl çalışanların sayısının (2.877) en fazla olduğu görülmektedir. Ardından 1-3 yıl çalışanların sayısı (2.525) gelmektedir. Bu oran yerel yönetimlerde de benzerlik 
göstermektedir. Yerel yönetimlerde 6-10 yıl çalışanların sayısı toplam çalışan sayısında en fazla paya (1.762) sahiptir. Bunu da yine 1-3 yıl çalışanların sayısı (1.371) takip etmektedir (mkk.gov.kg). Bu durum da ülkedeki devlet memurlarının hızlı bir sirkülasyon içinde bulunduğunu göstermektedir.

Neopatrimonyal yönetimlerde nepotist uygulamalara sıkça rastlanabilmektedir. Patronaj ağların hakim olduğu bu sistemde devlet kurumlarındaki pozisyonların kendi müşterisi konumundaki kişilerle birlikte potansiyel rakiplere dağıtılarak kitlesel başkaldırı riski en az seviyeye indirgenmeye çalışıır. Bu da kamu kurumlarının sayısı ile nepotist uygulamalar arasındaki paralel ilişkiyi ortaya koyar. Bu bağlamda müşteri veya rakip konumundakilere daha fazla fayda sağlamak için daha fazla kamu kurumunun ortaya çıkarılmasına neden olmaktadır (Melnikov, 2018, s. 69). Aşağıdaki grafikte de görüldüğü gibi Post-Sovyet ülkeler bazında ele alınan kamu kurumlarının sayısı Baltık ülkelerinde en az oranı teşkil etmektedir. Aynı zamanda ülke nüfusu, yüz ölçümü ve sektör dağılımı gibi hususlar dikkate alındığında ise Kırgızistan'daki bakanlıkların ve buna bağlı olarak kamu kurumlarının oldukça fazla sayıda olduğu anlaşılabilmektedir (Şkel, 2016, s. 99).

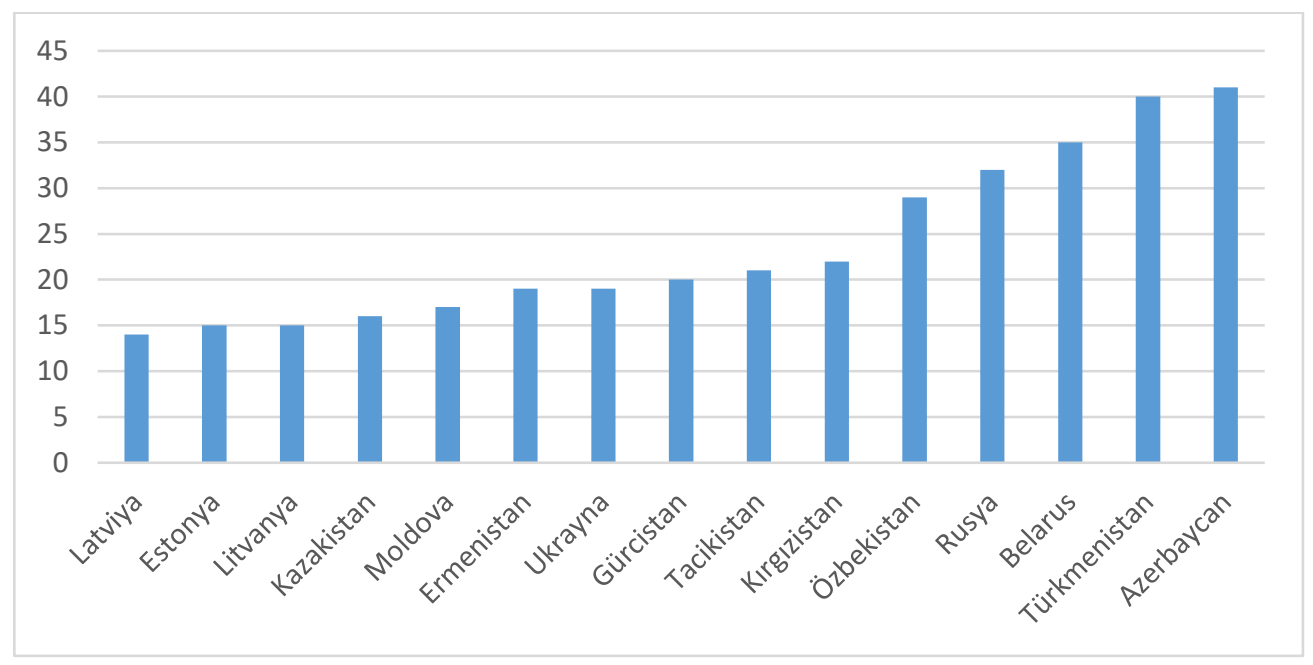

Şekil 1. Post-Sovyet Ülkelerdeki Bakanlık Sayıları (2015)

Kırgız Cumhuriyeti Kamu Hizmeti Kanunu'nda devlet memuru alım sürecinde mesleki tecrübe, uzmanlık, eğitim seviyesi, devlet dilinin kullanım düzeyi gibi kriterlerin etkili olduğu belirtilmiştir. Bu kapsamda kamu hizmetinde yerleştirilecek olan personel iç ve dış kaynaklardan temin edilebilir. İ̧ kaynak devlet kurumlarında çalışmakta olan personeli, dış kaynakta kamu hizmeti dışındaki adayları ifade etmektedir. Kurum dışından yapılacak olan seçim konusunda söz konusu devlet organları yetkilidir. Bu organlar tarafından yapılan rekabete dayalı yarışma kapsamında yerleştirilecek olan personel belirlenir. Kırgızistan'da devlet kurumları için personel alımı konusunda genel bir sınav yapılmamaktadır. Devlet dairelerinde oluşan personel açığı, o kurum yöneticisi tarafından DPS'ye bildirilerek ilana çıkılması sağlanır. Resmi kitle iletişim araçları vasıtasıyla duyurulan bu pozisyonlara başvuruda bulunanlar arasında söz konusu kurum tarafından bir yarışma düzenlenir. Başarılı sayılanlar ise yerleştirilmek üzere işe alınır (cbd.minjust.gov.kg).

Kırgızistan'da işten çıkarılma prosedürü Kırgız Cumhuriyeti İ̧̧ Kanunu’nda belirlenmiştir. Bu çerçevede kanunlarda ve diğer normatif yasal düzenlemelerde öngörülen durumlarda, yetkili devlet organlarının ve görevlilerin talebi üzerine, alkol, uyuşturucu gibi maddelerin etkisindeyken iş yerine gelmek, işveren tarafından sağlanan gerekli kişisel koruyucu ekipmanı kullanmamak gibi durumlarda işçi işten uzaklaştırılır ve yasal süreç bitinceye kadar maaş ödemesi yapılmaz. Ayrıca iş sözleşmesinin işverenin inisiyatifiyle feshedilmesi belli durumlarda gerçekleşir; kuruluşun tasfiyesi, organizasyonun yeniden düzenlenmesi ile bağlantılı olarak çalışan sayısının azaltılması, çalışanın sağık sorunları, çalışanın çalışma standartlarına uymaması, örgütün mülk sahibinin değişmesi (özel kuruluşlarda), çalışanın iş yükümlülüklerini defalarca yerine getirmemesi ve disiplinsiz davranması, geçerli sebepler dışında işe devamsızlık yapılması, çalışanın suç işlemesi bu durumlara örnek olarak gösterilebilir (cbd.minjust.gov.tr). 


\title{
4. Kırgızistan Kamu Hizmetinde İşe Alım ve Tasfiye Süreçlerinde Siyasetin Etkisi
}

Kırgızistan'da Sovyetler Birliği'nin mirası olarak işlemeye devam eden bürokrasi, bağımsızlıktan sonra hesap verebilirliğini kaybetmiş, bürokratik kurumlarda işe alma, seçme, yerleştirme, yükseltme gibi insan kaynakları fonksiyonlarında bozulmalar meydana gelmiştir. Bunun yerine, kamuoyuna sorumlu olmayan siyasi otoriteye bağımlı bir yapı ortaya çıkmıştır. Bağımsızlıkla birlikte devlet başkanı ve onun çevresindekiler, kamu hizmetindeki imkanları hatta yapılacak olan reformları kendi özel amaçlarına hizmet etmek için kullanmışlardır. Hazırlanan reformların faaliyete geçirilmesi konusunda da oldukça isteksiz davranmışlardır. Zira liyakat ve şeffaflığa dayanan bir bürokratik sistem, devlet yöneticilerinin kişisel kazanç ve siyasi rant elde etmesine engel olacaktır (Baimyrzaeva, 2011, s. 42). Bu konuda Kırgız Cumhuriyeti Din İşleri Komisyonu eski başkanı Zakir Çotayev (2020) şunları dile getirmiştir:

\begin{abstract}
"...eski bürokratların bu yeni dönemde girişimcilik faaliyetleriyle birlikte zengin ve seçkin bir gruba dönüştükleri bilinmektedir. Bu süreç doğal olarak eski Sovyet bürokrasi anlayışının terk edilerek yeni bir bürokratik anlayışın ortaya çıkmasını sağlamışıı. Yeni dönemde şahsi menfaatler ön plana çıkmaya başlamıştır. Yani devlet kurumları artık kişisel menfaatlerin odağına koyulmuştur. Bu anlayı̧ da Kırgızistan'da yolsuzlukların kapısını aralayan yeni koşulları beraberinde getirmiştir."
\end{abstract}

Doğal Afetler ve Ekoloji eski Bakan Yardımcısı Canuzakov (2020), Kırgız Sovyet Sosyalist Cumhuriyeti ve Kırgızistan'da bürokraside görev alma konusundaki farklı yaklaşımları şu şekilde ifade etmiştir:

\begin{abstract}
"SSCB döneminde bürokratik pozisyonlara yerleşmek için gerekli unsurlar liyakat ve tecrübeydi. Komünist Parti üyeliği de önemli kriterlerdendi, fakat o dönemde Komünist Parti üyesi olabilmek de haliyle zordu. Devlet kademelerinde orta ve üst düzey pozisyonlara yerleşmede, parti üyeliği gerekmekteydi. Kendini en iyi şekilde ispatlayabilenler parti üyeliğine alınabiliyordu. Üyelik kazanıldıktan sonra da o kişiye olan güven artar ve terfi yolları açıırdı. Ben de Komünist Parti'nin bir üyesiydim. Bağımsızlıktan sonra bu durum değişti. Kadro planlama, işe alma, yerleştirme, atama gibi süreçlerde akrabalık, tanışlık, farklı kanalların devreye girmesi gibi faktörler etkili olmaya başladı."
\end{abstract}

Eski bürokrat ve Büyük Elçi Mokeyev (2020) ise bu sözleri destekler nitelikte şunları ifade etmiştir:
"KSSC döneminde siyaset ve bürokrasi aynı kavramlara tekabül ediyordu. Komünist olmayan bürokrat olamazdı. Dolayısıyla Komünist Parti üyesi olanlar ancak bürokrasiye dahil olabilirdi. O dönemde her kurumun üst pozisyonlarında bulunanlar mutlaka Komünist Parti üyesiydiler. Dolayısıyla devlet işleri siyasi ideoloji ile iç içe geçmiş bulunmaktaydı. Nomenklatura sınıfına girebilmeleri için de önce Komsomol teşkilatında sonra Komünist Parti üyeliğinde bulunması ve güvenilir olmaları gerekiyordu. 0 dönemde sendikalar bile bu tabaka tarafından yönetilmekteydi. Görünüşte özerk olmasına rağmen tüm kurumlar Komünist Parti'ye bağııdı. Dolayısıyla komünist olmayanlar bürokrasiye yaklaşamazdı. Sovyetler Birliği dağıldıktan sonra ideolojinin bir önemi kalmadı. Bunun yerini akrabalık, hemşericilik gibi unsurlar aldı. Bu kapsamda bürokratların tecrübesine ve yeterliliğine önem verilmedi."

Kırgızistan'da bürokratik pozisyonlar için insan kaynakları uygulama aşamasında farklı dinamikler etrafında şekillenmektedir. Üst düzey pozisyonlara yerleşebilme veya kurum içinde yükselebilme imkânı her vatandaş için geçerli olmamaktadır. Bununla birlikte çalışanın yerleştiği kurum içinde kısa bir çalışma süreci geçmesine rağmen üst düzey pozisyonlara terfi edilme durumları da görülebilmektedir. Ayrıca herhangi bir yarışma yapıımadan işe alım işlemlerinin gerçekleşmesi durumuna da oldukça fazla rastlanabilir. Örneğin, 2005 yılında kamu kurumlarındaki boş pozisyonların \%60'ı rekabet dışı şekillerde doldurulmuştur. Bu kurumlarda personelin aldığı maaşların yetersizliği de memurların işlerini kötüye kullanmasına sebebiyet vermektedir. Bu doğrultuda memurların pragmatik bir bakış açısıyla bulundukları pozisyonlarda ek mali faydalar sağlamanın yollarını aramaya başladıkları gözlemlenmektedir (Bekbolotov, 2007, s. 8-9).

Kırgız bürokrasisinde geçmiş yönetimlerin ortak uygulamalarından biri nepotizmdir. Ülkedeki en yaygın görülen nepotizm biçimi, siyasi veya bürokratik seçkinler tarafından devlet kurumlarındaki pozisyonlara liyakat yerine kişisel kriterler çerçevesinde yerleştirmeler yapılmasıdır. Ülkenin ilk cumhurbaşkanlarının yakın çevresindeki kişilerin devletin üst düzey pozisyonlarına yerleştirildiği bilinmektedir. Örneğin, Bakiyev'in aile üyelerinin önemli devlet kurumlarına yönetici olarak yerleştirilmesi söz konusuydu. Bakiyev'in kardeşinin güvenlik güçlerini kontrol altında tutması, onun suçlulara karşı bir koruyuculuk görevi de üstlenmiş olması anlamına gelmekteydi. Bu doğrultuda da devlet kurumlarında yasadışı uygulamalar aracılığıyla kişisel kazanç elde etme olanağı ortaya çıkmaktaydı (Martini, 2013, s. 3). Tekebayev, 
Bakiyev'in oğlu Maksim'in Merkezi Kalkınma, Yatırım ve İnovasyon Ajansı'na başkan olarak atanmasını, nepotizmin ve ilkel bir komünal sistemin bir sonucu olduğunu vurgulamıştı. Ayrıca bu durumun ilerleyen dönemlerde derinleşerek aile içi çatışmalara yol açabileceği, hatta ülkenin bütünlüğüne tehdit haline gelebileceğini belirtmiştir (azattyk.org). İbraimov ise günümüzde halen bürokratik kurumlardaki nepotist uygulamaların artarak devam ettiğini vurgulamıştır (ibraimov, 2019). Bu tarz nepotist yöntemlerin yargı organlarında yaygın olmasıyla beraber, yürütme organlarının orta ve alt düzey hiyerarşisinde etkili olduğu görülmektedir. Ayrıca ülkedeki bütün kamu kurumlarında bu ve benzeri uygulamalarla karşılaşılabilmektedir (France ve Kuktuschka, 2019, s. 5).

Kırgızistan'da devlet memurları konusunda belirlenmiş yasal mevzuata rağmen farklı uygulamalarla karşılaşılabilmektedir. Liebert (2014), bu durumu aşağıdaki tablo ile açıklamaya çalışmıştır.

Tablo 1. Kırgızistan Kamu Hizmeti Sisteminde Yasal Kurallar ve Yaygın Uygulamalar

\begin{tabular}{|c|c|c|}
\hline $\begin{array}{l}\text { Insan Kaynakları } \\
\text { Uygulamaları }\end{array}$ & Kanunlar/Politikalar & Mevcut Uygulamalar \\
\hline İşe Alma & $\begin{array}{l}\text { Dual sistem: Açık ve kapalı } \\
\text {-Personel rezervleri aracılığıyla ve } \\
\text { (nitelikli harici adayların yokluğunda) } \\
\text { halka açık ve rekabete dayalı işe alma } \\
\text { sistemi }\end{array}$ & $\begin{array}{l}\text { Kapalı sistem etkisiz: Personel } \\
\text { rezervleri nadiren kullanılır } \\
\text {-Açık sistem etkisiz: Rekabetçi işe } \\
\text { alma süreci genellikle göstermelik } \\
\text { yapılır }\end{array}$ \\
\hline Seçim & $\begin{array}{l}\text {-Liyakate dayalı ve rekabet temelli seçim } \\
\text { işlemi }\end{array}$ & -Patronaj atamaları "ofis satışı" \\
\hline Yükseltme & $\begin{array}{l}\text {-Liyakate dayalı ve rekabet temelli seçim } \\
\text { işlemi }\end{array}$ & $\begin{array}{l}\text {-Patronaj ve "ofis satışı" } \\
\text {-Rüşvet ve diğer yasadışı yollarla } \\
\text { yükseltmenin sağlanması }\end{array}$ \\
\hline Ücretlendirme & $\begin{array}{l}\text {-Parlamento tarafından çıkarılan } \\
\text { düzenlemeye bağlı } \\
\text {-Performansa bağ ı olmayan ikramiyeleri } \\
\text { içerir }\end{array}$ & $\begin{array}{l}\text {-Çok düşüktür ve yolsuzluğa zemin } \\
\text { hazırlamaktadır }\end{array}$ \\
\hline İş Garantisi & $\begin{array}{l}\text { Fesih sebebi olmadıkça iş ve güvenlik } \\
\text { garantisi } \\
\text { Kamu hizmeti kurumu, memurların } \\
\text { haklarını koruma yetkisine sahiptir }\end{array}$ & $\begin{array}{l}\text { Yöneticilerin değişmesi durumunda } \\
\text { rotasyon veya işten çıkarmalar olur } \\
\text { Kamu hizmeti kurumları, memurların } \\
\text { haklarını korumada etkisiz }\end{array}$ \\
\hline $\begin{array}{l}\text { Performans } \\
\text { Değerlendirme }\end{array}$ & $\begin{array}{l}\text { Düzenli performans değerlendirmesi yok } \\
\text { Düzenli yeterlilik sınavları yapılır }\end{array}$ & $\begin{array}{l}\text { Performansı değerlendirmede etkili ve } \\
\text { objektif bir yol bulunmuyor } \\
\text { Yeterlilik sınavları performansı ölçmez }\end{array}$ \\
\hline
\end{tabular}

Kırgız Cumhuriyeti İş Kanunu'nda işten çıkarılma prosedürü ile ilgili açık bilgilere yer verilmiştir. Buna göre alkol ve uyuşturucu türevi maddelerin etkisi altındayken iş yerine gelmek, iş güvenliği kapsamında işverenin sağlamış olduğu ekipmanı kullanmaktan kaçınmak gibi durumlarda işçinin uzaklaştırma alması ve hukuki süreç tamamlanana kadar işçiye ödeme yapılmaması belirtilmiştir. Bununla birlikte, belli durumlarda işverenin iş akdini feshetme hakkı da bulunmaktadır. Kuruluşun tasfiye edilmesi, örgüt yapısının yeniden düzenlenmesine bağıı olarak çalışan sayısının azaltılması, çalışanın sağlık problemleri, çalışanın iş standartlarına aykırı hareket etmesi, özel kuruluşlarda mülk sahibinin değişmesi, çalışanın disiplin dışı davranışları veya suç işlemesi işverenin çalışanın iş sözleşmesini tek tarafı feshini gerektiren durumlardandır (cbd.minjust.gov.kg).

Kırgız Cumhuriyeti Sendikalar Federasyonu Başkanı Vera Bredihina, 90'lı yıllardan günümüze kadar sendikaların işlevini kaybettiğini belirtmiştir. Ona göre, Sovyetler Birliği döneminde dahi sendikalar çalışanların haklarını daha etkin savunabilmekteydi. Sendika komitesinden izinsiz olarak, kurum veya kuruluşların bir çalışanı tasfiye etmesi mümkün olmamaktaydı. Sendikaların bağımsızlık döneminde özellikle etkisiz hale getirilmesi, bürokraside istenilen şekilde 
personel alımı ve tasfiyesini ortaya çıkarmıştır. Bredihina, sendikaların günümüzde düştüğü durumda siyasi figürlerin etkili olduğunu vurgulamıştır (Bredihina, 2020).

Kırgızistan'da kamu hizmeti sistemi patrimonyal temel üzerine oturtulmuş, ülke kaynaklarının devletin kurumlarında patron-müşteri ilişkisi çerçevesinde tahsis edildiği bir siyasal sistemin varlığından söz edilebilmektedir. Bu sistem içinde memurlar için resmi kurallar ve gayri resmi veya şahsi ilişkiler arasında bir ayrım söz konusu değildir. Kamu kurumlarındaki yöneticilerin asıl amacı kurum veya devlet çıkarları için hareket etmekten çok şahsi zenginlik edinmektir (Liebert, 2014, s. 409). Böyle bir yapıdaki kurum içinde yöneticisinin işe alımlar veya işten çıkarmalar konusunda etkisi önem arz etmektedir. Bir devlet kuruluşu olan Kırgız Kömür İşletmeleri'nde iktidar değişimi sonrasında işinden çıkarılan Mirgül İsabekova (2020) bu durumu şu şekilde özetlemiştir:

\begin{abstract}
“Bir devlet kuruluşu olan 'Kırgız Kömür'de ailemin tanıdıkları aracıı̆ğıla 2015 yılında işe başladım. Söz konusu kurumun başındaki yöneticinin üyesi olduğu siyasi parti için seçim döneminde destekte bulunduğumuzdan dolayı bu işe girmeye hak kazandım. Kırgızistan'da parlamentoya girebilen her parti kendi aralarında anlaşmak suretiyle farkı kurumları paylaşmaktadırlar. 2017 yılında gerçekleşen seçimlerde cumhurbaşkanının değişmesinin ardından kurumumuzun yöneticisi de değişti. Yeni gelen yönetici kurumda olması gerektiğinden fazla çalışanın bulunduğu, bundan dolayı da mali konularda sıkıntıların meydana geldiğini belirtmesi üzerine ben de dahil olmak üzere kurumdan 17 çalışan çıkarıldı. Fakat kısa bir süre sonra kuruma yeni alımların olduğunu öğrendim."
\end{abstract}

Jurayev (2020) ise ülkenin bürokratik kurumlarındaki işten çıkarma uygulamalarına ilişkin şunları belirtmiştir:
“Işsten çıkarma prosedürü de gayri resmi şekilde işlemektedir. Kırgızistan'da işten çıkarmak için geçerli bir neden olması gerekiyor. İ̧ yerinde disiplinsizlik veya iş arkadaşları tarafından istenmemek gibi durumlar da bunların arasındadır. Kurumun mali durumları doğrultusunda çalışan sayısını azaltma politikaları kapsamında da işten çıkarmalar gerçekleşebiliyor. Hükümetin onayı doğrultusunda meydana gelen bu durum genelde kurumun başındaki yöneticinin yeni personel alma isteği doğrultusunda gerçekleşir. Ardından boşalan pozisyonlar için yeniden ilana çıkılır ve istenilen kişiler işe alınır. Mahkemelere olan güvensizlik nedeniyle işten çıkanlar yargı yolunu genellikle kullanmamaktadırlar."

Kırgızistan'da siyasi ve bürokratik yolsuzlukların yaygın olduğu bilinen bir gerçektir. Devlet kurumlarındaki pozisyonların birtakım yolsuzluk çerçevesinde yöneticinin ait olduğu klan, bölge, şehir gibi ortak grup içinde dağıtılmasının yanı sıra bu grup dışındaki kişilerin söz konusu pozisyonları satın alması da yaygın görünen uygulamalardandır. Toplum içinde kamu kurumlarında bir işe yerleşmenin belli bir maddi bedel gerektirdiği bilinmektedir. Öyle ki öğretmenlik mesleğinden en yüksek devlet memurluğuna kadar olan pozisyonların getirisi hesaplanarak bir satış bedeli oluşturulmuş durumadır (Liebert ve Tiulegenov, 2013, s. 93-94). Çokgezen, İçişleri Bakanlığı bünyesindeki pozisyonların getirisine göre 100 ila 50000 dolar arasında satıldığını belirtmiştir. Yapılan bu ödemelerin, söz konusu görev esnasında yolsuzluklardan elde edilecek olan maddi kazanç sayesinde kısa sürede çıkarılabildiğini vurgulamıştır. Zira alt ve üst düzey bürokratik kurumlarda, yapılacak işin önemine göre rüşvetin oranı da değişmektedir (Çokgezen, 2004, s. 91-92).

Siyaset bilimi uzmanı Emilbek Jurayev (2020) ülkedeki resmi kadrolaşma politikalarına karşı olarak gerçekleşen uygulamaları şu şekilde örneklendirmiştir:
“Komünist Parti'nin gücünü kaybetmesiyle Kırgızistan'da devlet kademelerinde işe alma veya işten çıkarma faaliyetleri gayri resmi olarak işlemeye başladı. İse alma konusunda devlet katında uzmanlık alanıyla ilgili yeterliliğine ilişkin herhangi bir sınav yapılmamaktadır. Fakat boş pozisyonlar için adayın mezuniyetine, puanlarına, tecrübesine vs. bakılır. Fakat bununla birlikte kişisel çıkarlar doğrultusunda gayri resmi şekilde akrabalık veya arkadaşlık, bazen de parti düzeyindeki ağlar doğrultusunda işe alımlar gerçekleştirilmekte. Iş̧e girmenin diğer bir yolu da rüşvet vermekten geçmektedir. Hatta devlet kademesindeki pozisyonlar bir 'yatırım aracı'na dönüşmüş durumda. Örneğin, gümrük veya vergi dairesinde bir pozisyona 100 bin som'luk rüşvet ile yerleşen bir şahıs bir yıl içinde 200 bin som elde ederek ödediği miktarın daha fazlasına sahip olmaktadır. Bu durum da kamu hizmetindeki pozisyonların adeta bir yatırım aracı olarak kullanılmasına neden olmakta."

Coldoşov ise günümüzde Kırgız siyasetinin bürokraside çalışanlar üzerindeki etkisini şu şekilde dile getirmiştir: 
“...Aslında bürokrasinin uzmanlaşması ve liyakatin gelişmesi için müsteşarlık kurumları oluşturuldu. Böylece alanında uzman kişilerin kurumları yönetmesi amaçlandı. Fakat bu makamlara cumhurbaşkanı tarafından yapılan atamalar, kurumların siyasi hegemonyanın etkisinden çıkmasını engellemektedir. Bu durum aslında Sovyet zihniyetinin bir ürünüdür. Zira SSCB döneminde bütün bürokratlar merkezi otorite adına hareket etmekteydi."

\section{Sonuç}

Günümüzde özellikle otoriter veya yarı-otoriter rejimlerin hakim olduğu devlet yapılarında siyasetin veya iktidarın devlet kurumları üzerindeki yoğun etkisini ifade etmek amacıyla neopatrimonyalizm kavramı kullanılmaktadır. Neopatrimonyal yönetim tarzını benimsemiş ülkelerde yasal-rasyonel, demokratik kurumların ve yasal mevzuatın bulunmasıyla birlikte iktidar odaklarının bu kurumlar üzerinde gayri şahsi ilişkilerinden söz edilmektedir. Sovyetler Birliği' nin dağılmasıyla ortaya çıkan devletlerin birçoğunda bu durum söz konusudur. Baltık ülkeleri gibi demokratikleşme sürecini başarıyla yürüten ülkeler hariç, özellikle petrol ve doğalgaz gibi yeraltı kaynaklarının yoğunlukla bulunduğu Orta Asya ülkelerinde bu tarz siyaset-bürokrasi ilişkileri günümüze kadar süregelmiştir. Post-Sovyet dönemde ortaya çıkan Türk Cumhuriyetleri arasında neopatrimonyalizmin Kırgızistan'da konsolide olamadığı söylenebilir. Bu durum diğer Türk Cumhuriyetlerinin aksine Kırgızistan'da hidrokarbon kaynakların bulunmamasıyla açıklanabilir. Zira bu kaynaklara sahip olan ve rantiyer devlet olarak da adlandırılan bu ülkelerde yeraltı kaynaklarının dış ülkelere satımından elde edilen gelir ile siyasi iktidarların güçlerini koruduğu bilinmektedir. Kırgızistan'da ise ülkedeki kıt kaynakların yönetici seçkinler tarafından paylaşımı, bu paylaşım esnasında yaşanan çatışmaların ise halk hareketlerine, dolayısıyla iktidar değişimlerine neden olduğu söylenebilir.

Kırgızistan'ın devlet kurumlarındaki alt düzey pozisyonlara kanunlar çerçevesinde fırsat eşitliğine dayalı seçimler yoluyla işe alımlar gerçekleştirilmelidir. Zira ülkede siyasilerin bürokratlar üzerindeki etkisinin yoğunluğundan söz edilmektedir. Özellikle devlet kurumlarında işe alma ve işten çıkarma süreçlerinde siyasi etkenler önemli rol oynamaktadır. Siyasi kurumlar içinde etkili olan klanlar, bölgesel ve yerel liderlik yapıları, yönetici seçkinler ve son zamanlarda trend haline gelen seçkinlerin kendi aralarında akrabalık kurma girişimleri gibi faktörler bürokrasideki baskı unsurlarından sayılmaktadır. Ülkedeki kamu kurumlarının insan kaynakları politikalarını yürütmekle sorumlu olan Devlet Personel Servisi'nin etkinliğinin olmadığı, bunun yerine söz konusu çıkar gruplarının önemli rol oynadığı söylenebilir. Bu kapsamda cumhurbaşkanının merkezinde olduğu bu sistemde onu çevreleyen çeşitli çıkar grupları tarafından yürütülen bir kamu hizmeti insan kaynakları planlaması mevcuttur. Ülkedeki resmî kurumların ve bu kurumlardaki pozisyonların sayısının gereğinden fazla olması, bürokrasideki patronaj ilişkilerin yüksek seviyelerde tutulmasına neden olmaktadır. Siyasi yöneticiler, devlet kurumlarındaki pozisyonları patron-müşteri ilişkileri kapsamında dağıtmakla beraber kendine rakip olabilecek kişi veya gruplara da sunarak olası çatışmaları önlemeye çalışmaktadırlar. Kırgızistan'ın bağımsızlığından beri onaylanan kamu hizmeti reformlarının eyleme geçirilmemesinin nedeni de karşılıklı çıkar ilişkisine dayanan bu süreci devam ettirmek olduğu iddia edilebilir.

Kırgızistan'ın bağımsızlık döneminde kamu kurum ve kuruluşlarında insan kaynakları planlama, seçme ve yerleştirme uygulamalarında kişisel ilişkilerin ön plana çıktığı söylenebilir. Kırgızistan’ın kamu kurumlarında liyakat ve şeffaflık ilkelerinin yoksunluğu, ülkedeki siyasilerin ve bürokratların yolsuzluklara karışmalarına neden olmaktadır. Kamuoyu yerine siyasi otoriteye bağımlı olan bürokratların resmî kurumları kişisel mülk olarak kullandığı görülmektedir. Işe alımlarda klan, kabile, akraba, hemşericilik gibi unsurların etkili olması, kurumlarda yapılan yolsuzlukların ortaya çıkmasını önlemek amaçlıdır. Ayrıca kurumlarda çalışanların kendi aralarında sahip oldukları yolsuzluk ile ilgili deliller de şantaj ilişkilerini meydana getirmektedir. İşten çıkarmaların da hukuk dışı yöntemlerle gerçekleştiği ülkede sendikaların işlevsiz olduğu görülmektedir. Zira sendikaların yöneticileri dahi siyasi otorite tarafından belirlenmekte ve denetim altında tutulmaktadır. Siyasi iktidarın değişimi esnasında bütün bürokratik kurumlardaki yöneticilerin değişmesi, akabinde personel değişimlerine de neden olmaktadır. Illk başta kurumun mali konularda sıkıntı yaşadığı gerekçe gösterilerek personel tasfiyesi gerçekleştirilmekte, ardından yeni personel alımı yapılmaktadır. Devlet memuru alımlarında herhangi bir merkezi sınavın yapılmadığı ülkede bu süreç kurum yöneticisi tarafından şekillendirilmektedir. Bu durum da bürokrasideki memurların amirine karşı sadakat olgusunu ortaya çıkarmaktadır. Bu da kamu kurumlarının asli görevini yerine getirmesini engelleyerek kişisel kazanç elde etmeyi temel amaç haline getirmektedir. 


\section{Kaynakça}

Akçakaya, M. (2016) "Bürokrasi Kuramları ve Türk Kamu Yönetiminde Bürokratik Sorunlar". Gazi Üniversitesi Iktisadi ve idari Bilimler Fakültesi Dergisi. 18 (3): 669-694.

Alkan, H. (2012). "Otoriter Yapılanma - Siyasal İstikrarsızlık Ayrımında Kırgızistan’da Anayasal Değişim”, Orta Asya'da Siyaset ve Toplum: Demokrasi, Etnisite ve Kimlik, Der. M. Turgut Demirtepe. 1-29. Ankara: USAK Yayınları.

Aydın, R. (2017). "Bürokrasiyi Toplumsal ve Siyasal Boyutuyla Ele Alan Kuramsal Yaklaşımlar". Hitit Üniversitesi Sosyal Bilimler Enstitüsü Dergisi. 10 (2): 993-1005.

Azattyk Kyrgyzstan. (2009). “O. Tekebayev: V Kırgızstane ustanovilsya nepotizm (O. Tekebayev: Kırgızistan'da nepotizm kuruldu)”. Erişim tarihi: 17.11.2020.. https://rus.azattyk.org/a/3056335.html

Bach, D. C. (2011). "Patrimonialism and neopatrimonialism: comperative trajectories and readings", Commonwealth \& Comperative Politics. 49 (3): 275-294.

Baimyrzaeva, M. (2011). "Analysis of Kyrgyzstan's administrative reforms in light of its recent governance challenges". International Public Management Review. 12 (1): 22-47.

Bekbolotov, K. (2007). On the path to ideal bureaucracy: The future of public service in Kyrgyzstan. Bishkek: Institute for Public Policy.

Bratton, M. ve Van de Walle, N. (1994). "Neopatrimonial Regimes and Political Transition in Africa", World Politics. 46 (4): 453-489.

Çevikbaş, R. (2014). "Bürokrasi Kuramı ve Yönetsel İşlevi", Ekonomi ve Yönetim Araştırmaları Dergisi. 3 (2): 75-102.

Çokgezen, M. (2004). "Corruption in Kyrgyzstan: the facts, causes and consequences". Central Asian Survey. 21 (1): $79-$ 94.

Dursun, D. (1992). "Bürokrasi Teorisi ve Yönetim”, Sosyal Siyaset Konferansları Dergisi. 37-38: 133-149.

Erdman, G. ve Engel, U. (2007) "Neopatrimonialism Reconsidered: Critical Review and Elaboration of an Elusive Concept". Commonwealth and Comperative Politics. 45 (1): 95-119.

Eryılmaz, B. (2012). Kamu Yönetimi: Düşünceler, Yapılar, Fonksiyonla., Kocaeli: Umuttepe Yayınları.

Fisun, O. (2012). "Rethinking Post-Soviet Politics From a Neopatrimonial Perspective", Demokratizatsiya: The Journal of Post-Soviet Democratization. 20 (2): 87-98.

France, G. ve Kukutschka, R. M. (2019). Kyryzstan: Overview of corruption and anti-cprruption. Transparency International.

Hegel, G. W. F. (2001) Philosophy of Right. Kitchener: Batoche Books.

Ilkhamov, A. (2007) "Neopatrimonialism, interest groups and patronage networks: the impasses of the governance system in Uzbekistan", Central Asian Survey. 26 (1): 65-84.

İbraimov, O. (2019). “Podsudnıye Prezidentı Kırgızstana. To li yeşyo budet? (Kırgızistan’ın Yargıdaki Cumhurbaşkanları. Tekrar olacak mı?)”. Azattyk Kyrgyzstan. https://rus.azattyk.org/a/29952556.html (Erişim Tarihi: 17.11.2020).

Kırgız Cumhuriyeti Adalet Bakanlı̆̆ı. Kırgız Respublikasının Emgek Kodeksi (Kırgız Cumhuriyeti iş̧ Kanunu), http://cbd.minjust.gov.kg/act/view/ky-kg/1505 (Erişim Tarihi: 10.09.2020).

Kırgız Cumhuriyeti Devlet Personel Servisi. Kırgız Respublikasının Mamlekettik Kadr Kızmatı Cönündö Cobo (Kırgız Cumhuriyeti Devlet Personel Servisi Tüzüğü). https://mkk.gov.kg/contents/view/id/60/pid/56 (Erişim Tarihi: 23.09.2020).

Kunysz, N. (2012) "From sultanism to neopatrimonialism? Regionalism within Turkmenistan". Central Asian Survey. 31 (1): 1-16. 
Lai, J. (2014). "“Patrimonial Bureaucracy" and Chinese Law: Max Weber's Legacy and Its Limits". Modern China. 41 (1): 40-58.

Liebert, S. (2014). "Challenges of Reforming the Civil Service in the Post-Soviet Era: The Case of Kyrgyzstan". Review of Public Personnel Administration. 34 (4): 403-420.

Liebert, S. ve Tiulegenov, M. (2013). "Public Administration in Kyrgyzstan". Public Administration in Post-Communist Countries. 69-99. Ed. S. Liebert, S. Condrey ve D. Goncharov. New York: CRC Press.

Livşin, A. (2018). "Kommunistiçeskaya partiya v sisteme vlasti v SSSR (SSCB Yönetim Sisteminde Komünist Parti)", Konturı Globalnıh Transformatsii. 11 (2): 13-35.

Martini, M. (2013). "Overview of corruption and anti-corruption in Kyrgyzstan". U4 Expert Answer. Transparency International.

Melnikov, K. (2017). "Klientalizm kak opredelyayuşaya çerta neopatrimonalnıh rejimov (Neopatrimonyal rejimlerin ayrıt edici özelliklerinden olarak klientalizm)", Voprosı Uprvaleniya. 25 (1): 71-78.

Melnikov, K. (2018). "Neopatrimonializm: Klassifikatsiya kak sposop preodoleniya kontsepynıh natyajek (Neopatrimonyalizm: Kavram stresini aşmak için bir sınıflandırma)". Polis. Political Studies. (2): 68-81.

Peachey, J. T. (2006). "Becoming Bureaucracy: Paradox As Process". The Cambridge Journal of Anthropology. 26 (1): 2450.

Sager, F. ve Rosser, C. (2009). "Weber, Wilson, and Hegel: Theories of Modern Bureaucracy". Public Administration Review. 69 (6): 1136-1147.

Shaw, C. K. Y. (1992). "Hegel's Theory of Modern Bureaucracy". The American Political Science Review. 86 (2): 381-389.

Sultanbekov, K. (2016). "Patrimonializm i osobennosti skladıvaniya patrimonialistiçeskih otnoşeniy v Kırgızstane (Kırgızistan'da patrimonyalizm ve patrimonyalist ilişkilerin oluşumu)", Nauka, Tehnika i Obrozovanie, 28 (10): 108110.

Şkel, S. (2016). "Neopatrimonalnıye praktiki i ustoyçivost avtoritarnıh rejimov Evrazii (Avrasyanın otoriter rejimlerinin neopatrimonyal uygulamaları ve sürdürülebilirliği)”. Politiya. 83 (2): 94-107.

Voslenskiy, M. (1990). Nomenklatura: Gospodstvuyuşiy klass Sovyetskogo Soyuza (Nomenklatura: Sovyetler Birliği'nin Yönetici Sınıfı). London: OPI.

Weber, M. (2004). Sosyoloji Yazıları. Çev. Taha Parla. İstanbul: iletişim Yayınları

Weber, M. (2012). Ekonomi ve Toplum. İstanbul: Yarın Yayınları.

Weber, M. (2017). Meşru Egemenlik. Çev. Latif Boyacı. İstanbul: Yarın Yayınları.

Weingrod, A. (1968). "Patronage, and Political Parties", Comperative Studies in Society and History. 10 (4): 377-400.

\section{Mülakatlar}

Çotayev, Z. Mülakat: Ömer Faruk Karaman, Bişkek, 16.11.2020.

Canuzakov, K. Mülakat: Ömer Faruk Karaman, Bişkek, 19.11.2020.

Mokeyev, A. Mülakat: Ömer Faruk Karaman, Bişkek, 11.11.2020.

Bredihina, V. Mülakat: Ömer Faruk Karaman, Bişkek, 13 Kasım 2020.

İsabekova, M. Mülakat: Ömer Faruk Karaman, Bişkek, 10 Eylül 2020.

Jurayev, E. Mülakat: Ömer Faruk Karaman, Bişkek, 3 Kasım 2020.

Coldoşov, A. Mülakat: Ömer Faruk Karaman, Bişkek, 27 Kasım 2020. 